\title{
Correction to: Evaluation of the aircraft fuel economy using advanced statistics and machine learning
}

\author{
S. Baumann ${ }^{1}$ (1) $\cdot$ T. Neidhardt $^{1} \cdot$ U. Klingauf ${ }^{1}$
}

Published online: 27 July 2021

๑) Deutsches Zentrum für Luft- und Raumfahrt e.V. 2021

\section{Correction to: CEAS Aeronautical Journal https://doi.org/10.1007/s13272-021-00508-8}

Unfortunately, errors were mistakenly included in the article during publication, relating to a partially misleading presentation of numbers and equations as well as missing sentence parts and citations in the text. Therefore, a subsequent correction of the article is necessary to preserve the integrity of the research literature. It is explicitly stated that the corrections do not alter the conclusion of the article, but contribute significantly to a better understanding. The corrections will be incorporated into the original article. We thank you for your understanding and apologize for this inconvenience.

The corrigendum/erratum of the affected text passages is provided as follows:

\begin{tabular}{|c|c|c|c|}
\hline Section & Page & Incorrect text passage & Corrected text passage \\
\hline 1 & 1 & $\begin{array}{l}\text { In } 2018 \text {, the overall fuel contribution worldwide } \\
\text { was at } 23.5 \text { consumption of a flight are, for } \\
\text { example, the aerodynamic drag of the aircraft, the } \\
\text { efficiency of the engines, the travel distance, the } \\
\text { aircraft weight and the altitude profile (see [2]). }\end{array}$ & $\begin{array}{l}\text { In } 2018 \text {, the overall fuel contribution worldwide was at } \\
23.5 \% \text { [1]. The main factors influencing the fuel con- } \\
\text { sumption of a flight are, for example, the aerodynamic } \\
\text { drag of the aircraft, the efficiency of the engines, the } \\
\text { travel distance, the aircraft weight and the altitude profile } \\
\text { (see [2]). }\end{array}$ \\
\hline- & $\begin{array}{l}\text { 1, Address } \\
\text { footer }\end{array}$ & 64289 & 64287 \\
\hline 3 & 3 & $\begin{array}{l}\text { The aim of providing evidence for an fuel effi- } \\
\text { ciency increase is, therefore, to be able to reliably } \\
\text { derive quantitative assessments of the savings } \\
\text { potential of retrofits down to the range of around } \\
0.3-0.5 \text { considering the implications of the tech- } \\
\text { nology used. }\end{array}$ & $\begin{array}{l}\text { The aim of providing evidence for an fuel efficiency } \\
\text { increase is, therefore, to be able to reliably derive quan- } \\
\text { titative assessments of the savings potential of retrofits } \\
\text { down to the range of around } 0.3-0.5 \% \text { while considering } \\
\text { the implications of the technology used. }\end{array}$ \\
\hline 6.1 & 6 & $\begin{array}{l}\text { Only in this measuring range, the manufacturer's } \\
\text { uncertainty information on systematic errors of } \\
\text { up to }+0.5 \text { characteristics are unknown }\end{array}$ & $\begin{array}{l}\text { Only in this measuring range, the manufacturer's uncer- } \\
\text { tainty information on systematic errors of up to }+0.5 \% \\
\text { applies. However, the real flow meter characteristics are } \\
\text { unknown. }\end{array}$ \\
\hline 6.1 & 7, Eq. 14 & $\Delta \mathrm{SR}=-\frac{\mathrm{TAS}}{\mathrm{FF}^{2}} \Delta \mathrm{FF}+\frac{1}{\mathrm{FF}} \mathrm{FF} \Delta \mathrm{TAS}$ & $\Delta \mathrm{SR}=-\frac{\mathrm{TAS}}{\mathrm{FF}^{2}} \Delta \mathrm{FF}+\frac{1}{\mathrm{FF}} \Delta \mathrm{TAS}$ \\
\hline
\end{tabular}

The original article can be found online at https://doi.org/10.1007/ s13272-021-00508-8 .

S. Baumann

baumann@fsr.tu-darmstadt.de

1 Institute of Flight Systems and Automatic Control,

Technische Universitaet Darmstadt, Otto-Berndt-Str.

2, 64287 Darmstadt, Germany 


\begin{tabular}{|c|c|c|c|}
\hline Section & Page & Incorrect text passage & Corrected text passage \\
\hline 6.1 & $\begin{array}{l}\text { 7, Eq. } 14,15 \\
\& 17\end{array}$ & Formatting: $\Delta, \overline{\mathrm{p}}, \mathrm{q}, \mathrm{T}$ & Formatting: $\Delta, \bar{p}, q, T$ \\
\hline 6.1 & 7 & $\begin{array}{l}\text { The current maximum values of the error reach } \\
\text { orders of magnitude of } 10-15 \% \text {, while the aver- } \\
\text { age errors are in therange of } 0.2 \text { to } 0.5 \% \text { and } \\
\text { thus fall within the range of savingspotential of } \\
\text { different retrofits. }\end{array}$ & $\begin{array}{l}\text { The current maximum values of the error reach orders of } \\
\text { magnitude of } 10-15 \% \text {, while the average errors are in the } \\
\text { range of } 0.2 \text { to } 0.5 \% \text { and thus fall within the range of sav- } \\
\text { ings potential of different retrofits. }\end{array}$ \\
\hline 6.1 .1 & 7 & $\begin{array}{l}\text { The systematic error in the fuel flow measure- } \\
\text { ment could be identified in the range of about } \\
0.5 \text { manufacturer's information. }\end{array}$ & $\begin{array}{l}\text { The systematic error in the fuel flow measurement could be } \\
\text { identified in the range of about } 0.5 \% \text { based on the manu- } \\
\text { facturer's information. }\end{array}$ \\
\hline 6.1 .1 & 8 & $\begin{array}{l}\text { If the relative size of the measurement errors is in } \\
\text { the range of the savings potential of an individual } \\
\text { retrofit (e.g. in the range of } 0.3-0.5 \text { with the previ- } \\
\text { ously mentioned parameters (see Sect. } 2 \text { ). }\end{array}$ & $\begin{array}{l}\text { If the relative size of the measurement errors is in the range } \\
\text { of the savings potential of an individual retrofit (e.g. in } \\
\text { the range of } 0.3-0.5 \% \text { ), the effectiveness can no longer } \\
\text { be proven with the previously mentioned parameters (see } \\
\text { Sect. 2). }\end{array}$ \\
\hline 6.2 & 8 & $\begin{array}{l}\text { However, the test result for the Wilcoxon rank sum } \\
\text { test identify an actual efficiency gain of } 0.5 \text { sig- } \\
\text { nificant, even with a small sample size of } N=40 \text {. }\end{array}$ & $\begin{array}{l}\text { However, the test result for the Wilcoxon rank sum test } \\
\text { identifies an actual efficiency gain of } 0.5 \% \text { as significant, } \\
\text { even with a small sample size of } N=40 \text {. }\end{array}$ \\
\hline 6.4 & 10 & $\begin{array}{l}\text { The metrics are obtained from the test are the } \mathrm{p} \\
\text { value for the probability of observing a test sta- } \\
\text { tistic as or more extreme than the observed value } \\
\text { under the null hypothesis and the test decision, a } \\
\text { logical for a rejection of the null hypothesis ( } h= \\
\text { 1) or a failure to reject the null hypothesis } h=0 \\
\text { at a specific significance level (see [32]). For this } \\
\text { investigation, } p \text { values less than } 5 \% \text { are used as a } \\
\text { criterion for accepting significance. }\end{array}$ & $\begin{array}{l}\text { The metrics are obtained from the test are the } \mathrm{p} \text { value for } \\
\text { the probability of observing a test statistic as or more } \\
\text { extreme than the observed value under the null hypothesis } \\
\text { and the test decision, a logical for a rejection of the null } \\
\text { hypothesis }(h=1) \text { or a failure to reject the null hypothesis } \\
(h=0) \text { at a specific significance level (see [32]). For this } \\
\text { investigation, } p \text { values less than } 5 \% \text { are used as a criterion } \\
\text { for accepting significance. }\end{array}$ \\
\hline 6.4 & 11, Table 1 & $\begin{array}{l}p(-) h(-) r(-) \\
<0.110 .84\end{array}$ & $\begin{array}{l}p(-) h(-) r(-) \\
<0.110 .84\end{array}$ \\
\hline
\end{tabular}

Publisher's Note Springer Nature remains neutral with regard to jurisdictional claims in published maps and institutional affiliations. 